\title{
Reading, Writing and Linguistics Areas in French as a Foreign Language
}

\author{
Senem Seda Şahenk Erkan \\ School of Foreign Languages, Marmara University, Turkey
}

Copyright $\bigcirc 2017$ by authors, all rights reserved. Authors agree that this article remains permanently open access under the terms of the Creative Commons Attribution License 4.0 International License

\begin{abstract}
Globalization and technological developments have caused several students to start their academic careers with the challenge of mastering at least two languages. The purpose of this study is to examine the importance of reading, linguistics, and writing areas in French as a Foreign language (FFL) at the A2 (Waystage) language level. This study was prepared using a mixed method, with reading and writing tests (quantitative method), in which 120 students participated, and interviews (qualitative method) with 20 students. The results of this research indicated that the consequences of the reading and writing test are very high (their scores were between 85-100 points). The results of the interviews justified that the learners succeed in their reading and writing activities. In addition, they indicated that they had no negative feelings toward this application.
\end{abstract}

Keywords French as a Foreign Language (FFL), A2 (Waystage) Language Level, Reading, Writing and Linguistics Areas

\section{Introduction}

During the $21^{\text {st }}$ century, humanity has witnessed the transformation of western civilization into a global civilization within people's educational, political, economic, social, and technological lives. Globalization has brought unprecedented economic and technological opportunities along with massive, complex problems with enormous destructive power [1].

Today, learners will profit from a particular form of networking - mentorship - which is perhaps the most powerful form of social capital. Some $21^{\text {st }}$ century themes have become increasingly important within a global economy [2]:

(i). Individuality,

(ii). Connectedness, and

(iii). Non-cognitive attributes.

Bringing learners into connection with the cultures of other countries, where the target language is spoken, is a priority for $21^{\text {st }}$ century teachers and also students. Due to the differences realized in the $21^{\text {st }}$ century world, learning of foreign languages has gained more and more importance [3]. Students want to learn foreign languages not only to communicate, but also as a means to find contacts, meet people, and create new partnerships. The focus of such language acquisition is not on grammar, memorization, and learning from rote, but rather on using language and cultural knowledge as a means to connect with others around the globe [4]. Learning of foreign languages is defined as the use of insights and methods of theoretical linguistics for gaining knowledge in another, non-linguistic discipline, such as ethnology, sociology, law, or literary studies, as the application of insights from linguistics in practical fields related to language, such as language teaching and translation.

Conceptually, CEFR involves the many ways in which contexts of learning differ in terms of purpose, students, and teaching methodology [5], comprising two frameworks:

(i). It provides a common language for discussing language learning and teaching and

(ii). It assures a set of reference proficiency levels.

The six language levels of CEFR are (A1 (Breakthrough), A2 (Waystage), B1 (Threshold), B2 (Vantage), C1 (Effective operational proficiency), and C2 (Mastery)) that offer a neutral point to which any specific context of learning can be referred. These language levels reflect a progression of steps sufficiently accessible as learning targets but also distinct as learning achievements; they have been developed in an organic way in response to need [6]. In A2 language level, the learners can read very short, simple texts. They can find specific, predictable information in simple everyday material such as advertisements, prospectuses, menus and timetables and they can understand short simple personal letters. In addition, they can write short, simple notes and messages, a very simple personal letter, for example thanking someone for something [5].

The four traditional language skills (listening, reading, speaking, and writing) are essential components of integral 
Foreign Language(s) (FL) classes, including French as a Foreign Language (FFL) classes. Fostering foreign language skills is essential for a mid-sized emerging economy like Turkey, as foreign language learning contributes to improved national performance in the global knowledge economy [7]. But it is important to determine whether these classes are effective in helping our students become communicatively competent. Learning to read in L1 as well as L2 or any subsequent languages consists of more than learning vocabulary. Lexis is formed often as the most important area one needs to master to become a successful reader. However, one should not overlook other important complementary aspects, some of which are also mentioned by Grabe and Stoller (2002) as desirable reading strategies that should become automatized [8]. In brief, the aim of this study is to investigate the importance of linguistics, reading, and writing areas in French as a Foreign language (FFL) at the A2 (Waystage) language level.

\subsection{Developing Reading, Writing and Linguistic Skills in Foreign Language(s)}

During the action of teaching foreign languages, it is easy to see why the ability to read in a second or foreign language can be considered one of the most important skills for people in an international setting. Subsequently, there has been increasing focus on reading in recent years [9], [10] and [11]. Reading is probably the most extensively researched language skill.

Reading materials are considered one of the essential sources for acquiring comprehensible input, and therefore reading has always been a significant aspect of language learning [12]. Since the 1980s, significant improvements have been made in research on reading, both in first, foreignand second-language contexts. In addition, reading comprehension is a complex process, and different components of metalinguistic awareness are useful for reading comprehension. One such skill is the morphological and syntactical awareness of and ability to manipulate the smallest meaningful units (morphemes) with the rules of sentences (syntax) in spoken and written language [13]. When reading in foreign languages, metalinguistic awareness (MA) is the ability to focus on and manipulate the formal properties of language, specifically the ability to analyze, think about, talk about, or play with language as an object separate from its meaning in or out of context.

In FL classes, a teacher can prepare learning exercises for writing with students' own words in different subjects and also in different formats such as writing a post card, an e-mail, a letter, or an essay. In this concept, McCarthey and Garcia (2005) explained that students' writing practices and attitudes toward writing were improved by home backgrounds and classroom contexts [14]. In addition, Graham and Herbert (2011) stated that writing develops students' comprehension, reading fluency, and vocabulary, and increasing how much students write enhances such reading comprehension [15].

In fact, reading-writing connections and interactions can be realized together with various perspectives and with diverse factors and variables during the FFL lessons. The functional effects of reading on writing and of writing on reading also have a positive reflection on external goals such as success in academic courses. Reading and writing activities also develop students' phonemic, orthographic, semantic, syntactic and pragmatic knowledge.

From another perspective, Kinsella (2009: 20) presents reading-writing studies' findings as listed below [16]:

(i). "Reading widely and regularly contributes to the progress of writing skill,

(ii). Good writers were read to as children,

(iii). Increasing one's reading frequency has a positive influence on developing writing than does solely increasing writing frequency, and

(iv). Developmental writers must see and analyze multiple effective examples of the various kinds of writing they are being asked to produce (as well as ineffective examples); they cannot, for example, be expected to write successful essays if they are primarily reading narrative texts."

\section{Method}

This study composed the data using mixed methods: quantitative (a semi-prepared interview form) and qualitative researching methods (reading comprehension and writing tests). The triangulation strategy of mixed methods is illustrated below [17]. 


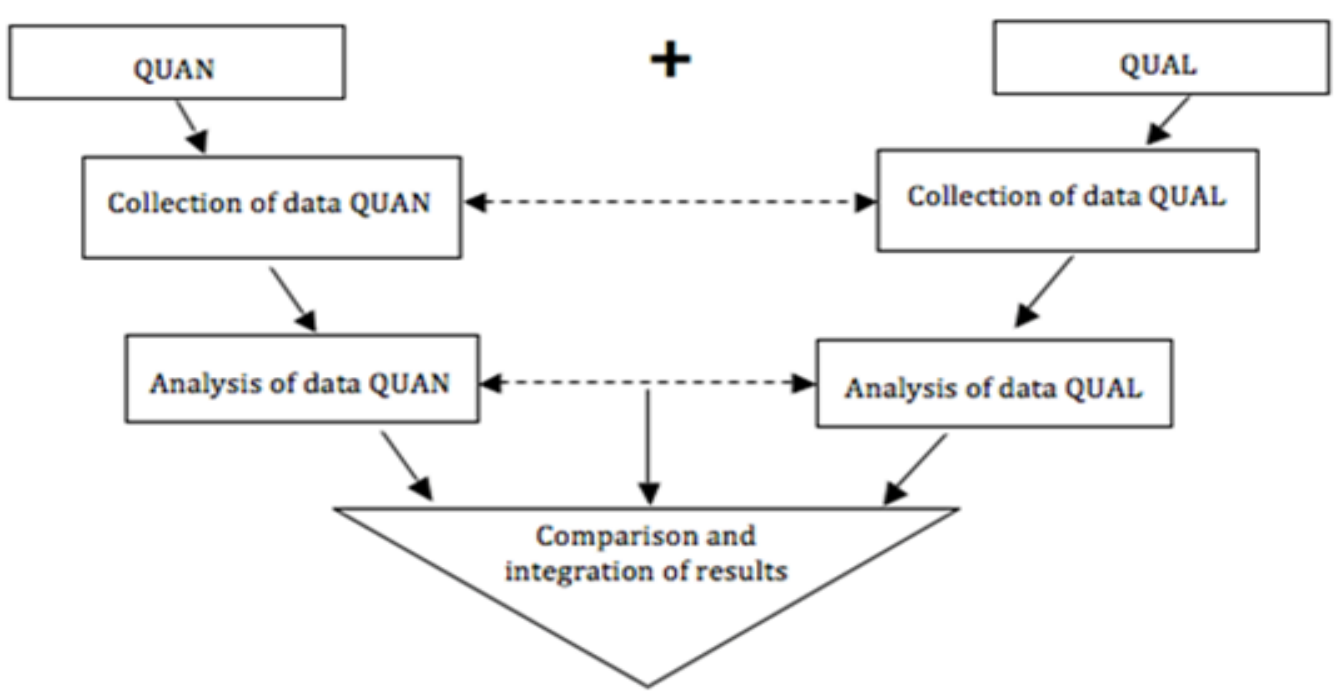

Reference: [17]

In the Scheme 1, the triangulation strategy of mixed-method study represents the quantitative and qualitative data that is collected, analyzed, and interpreted in the objectives of comparison and integration the results of the study.

Scheme 1. The triangulation strategy of mixed-method study

\subsection{Sample}

In the academic year 2016-2017, this research drew data from a sample composed of 120 Turkish university students (70 girls and 50 boys) at Marmara University. These students worked in the English teaching department at Marmara University in Istanbul, Turkey. They taught French as a foreign language in $3^{\text {rd }}$ and $4^{\text {th }}$ grades two hours per week. They obtained nearly an A2 language level in French. This study employs reading-writing tests and an interview as part of research methodology. The FFL learners tried to read and write their language of study through this internet-based study, built through the application of an Internet site [18].

\subsection{Reading-Writing Test}

The reading-writing test is prepared with 3 questions scoring a total of 100 points. The first question, worth 20 points, asked the respondents to describe the place called Nauplie. Secondly, the students explained what they would do in Nauplie, worth 30 points. Lastly, participants wrote a place presentation card with a minimum of 100 words and 10 sentences, worth 50 points.

An example of a test paper is presented below:

\begin{tabular}{|ll|}
\hline After reading the text presented below, you can answer these questions: & \\
1) Describe this place called "Nauplie" in your own words. & $(20$ pts. $)$ \\
2) What can you do if you visit Nauplie? & $(30$ pts. $)$ \\
3) Write another place presentation card with maximum 100 words and 10 sentences & $(50$ pts. $)$ \\
\hline
\end{tabular}

\subsection{Application}

Several Internet sites provide aid with French reading texts with comprehension and also writing activities for the FFL classroom. For example, when the teacher or the learner clicks on http://www.bonjourdefrance.com/exercices/nauplie-vous-invite-html, he/she sees several questions to answer, and after writing the responses, he/she learns if they are true or not and can also see the false parts of his/her paragraph responses. Finally, the respondent can also access a different place presentation card in French.

This research is based on the reading, comprehension, and writing activities regarding the text titled "Nauplie vous invite (Nauplie invite us)" site, as seen below: 
Table 1. Internet site of "Nauplie vous invite (Nauplie invite us)"

\begin{tabular}{|c|c|}
\hline Text in French Language: A2 Language Level & Text in English Language: A2 Language Level \\
\hline $\begin{array}{l}\text { Coucou Michelle! } \\
\text { Je t'écris pour t'inviter à passer un été inoubliable dans ma ville, Nauplie, une } \\
\text { petite ville pittoresque du Péloponnèse. } \\
\text { Il y a beaucoup de choses qu'on pourrait faire! Tout d'abord on visitera la } \\
\text { forteresse de «Palamidi», et pourquoi ne pas monter les escaliers extérieurs } \\
\text { pour admirer une vue splendide sur Nauplie! Puis on se promènera dans les rues } \\
\text { pavées de la vieille ville et on passera par l'église de St. Spyridon, le bâtiment } \\
\text { de la première École Militaire de Grèce et la bibliothèque «Palamidis», pour } \\
\text { arriver à la place Syntagmatos et s'asseoir à un des cafés de la place qui ont vue } \\
\text { sur la vieille horloge de la ville. } \\
\text { On continuera avec une visite au musée archéologique ou au musée folklorique } \\
\text { et puis le port de Nauplie est tout près pour prendre le bateau jusqu'à la } \\
\text { forteresse «Bourtzi» qui se trouve sur une île au milieu du golfe d'Argolida. Si } \\
\text { on veut faire de la natation, la plage d'«Arvanitia» n'est pas loin. On doit } \\
\text { prendre la rue piétonne sous les rochers d'«Akronafplia» pour y arriver! } \\
\text { Je t'attends! } \\
\text { Bises, } \\
\text { Antigone }\end{array}$ & $\begin{array}{l}\text { Dear Michelle, } \\
\text { I write to invite you to pass an unforgettable summer in my city, } \\
\text { Nauplie, which is located in the beautiful and small area of } \\
\text { Péloponnèse. } \\
\text { There are many things we could do together! First of all, we can } \\
\text { visit the fortress of Palamidi, and climb the stairs to admire a } \\
\text { splendid view of Nauplie! Then we can walk through the large } \\
\text { streets of the old town and pass through the church of St. } \\
\text { Spyridon, the building of the first Military School of Greece, and } \\
\text { the library, Palamidis, to reach Syntagmatos Square and sit in one } \\
\text { of the cafes in the square with a view of the city's old clock. } \\
\text { We will continue with a visit to the archaeological museum or the } \\
\text { folk museum. The port of Nauplie is very close to the fortress } \\
\text { Bourtzi, which we can access by boat, situated on an island in the } \\
\text { middle of Argolida lake. If you want to swim, the beach of } \\
\text { "Arvanitia" is not so far. You have to take the pedestrian street } \\
\text { under the rocks of Akronafplia to go there! } \\
\text { I anxiously await your reply! } \\
\text { Kindest Regards, } \\
\text { Antigone }\end{array}$ \\
\hline
\end{tabular}

Reference: [18]

\subsection{Semi-Prepared Interview Form}

A semi-prepared interview form is composed of 3 questions. 20 learners participated in the interview. The first question was designed to analyze French reading-writing activities. The second question sought to explain the positive effects of this research. The third question described the negative consequences of this application in FFL classes.

\section{Findings}

The findings of the reading-writing test and the semi-prepared interview form are demonstrated step by step in this section.

\subsection{Findings of Reading - Writing Test}

The findings of the reading-writing test are explained in Table 2.

Table 2. Findings of reading comprehension and writing test

\begin{tabular}{|c|c|c|c|}
\hline Reading-writing test & Scores & $\mathbf{N}$ & \% \\
\hline \multirow{2}{*}{$\mathbf{1}^{\text {st }}$ question } & $0-10$ pts. & 6 & 5 \\
& $11-20$ pts. & 114 & 10 \\
\multirow{2}{*}{$2^{\text {nd }}$ question } & $0-15$ pts. & 108 & 90 \\
\hline \multirow{2}{*}{$3^{\text {rd }}$ question } & $16-30$ pts. & 12 & 10 \\
& $0-19$ pts. & 108 & 90 \\
\hline \multirow{2}{*}{ Final score } & $20-50$ pts. & 0 & 10 \\
& $0-49$ pts. & 108 & 90 \\
\hline
\end{tabular}

As seen in Table 1, the students scored 11-20 points on the first question. Furthermore, they also earned 16-30 points on the second question. In addition, they obtained 30-60 points on the third question. In the result of this reading-writing test, the scores of the university students indicated that nobody scored 0-49 points, only 12 learners obtained 51-84 points, and the remaining learners earned $85-100$ points.

Table 3. Findings of semi-prepared interview form

\begin{tabular}{|c|c|c|c|c|}
\hline & Questions of semi-prepared interview form & Answers of semi-prepared interview form & N & $\mathbf{\%}$ \\
\hline \multirow{2}{*}{$\mathbf{1}$} & Explain in detail which parts of your answers you & I understand easily the text given. & 20 & 100 \\
& can answer easily or not & I structured true sentences in French. & 10 & 50 \\
\hline \multirow{2}{*}{$\mathbf{2}$} & \multirow{2}{*}{ What are the positive results of this study? } & This study improves my lexical knowledge of French. & 10 & 50 \\
This study improves my linguistic knowledge in French. & 20 & 100 \\
\hline $\mathbf{3}$ & What are the negative consequences of this research? & This research has no negative aspects. & 20 & 100 \\
\hline
\end{tabular}




\subsection{Semi-Prepared Interview Form}

The open questions and findings of the semi-prepared interview form are shown in Table 3.

As seen in Table 2, in the first question, the students thought they could write the answers easily. Furthermore, half of the learners approved that they formed nearly correct phrases in French. In addition, on the second question, half of the learners indicated that this research allowed them to improve their French vocabulary knowledge. On the other hand, the students indicated that this study allows them to obtain new linguistic knowledge of French. Finally, they believed that this application had no negative impacts.

\section{Conclusions}

This research is composed of two parts, quantitative and qualitative data, as in the other mixed studies. The results of the reading-writing test, structured by the reading-writing test (quantitative method), verified that nearly all students (120 learners) earned high scores (85-100 points). Finally, after the interviews (qualitative method), everybody indicated that they had good opinions about this application.

\subsection{Discussions}

This study was formed by the reading-writing test (quantitative test) and semi-prepared interview (qualitative method) forms. In the results of this reading-writing test, nearly everybody scored high points (85-100 points). As seen in the consequence of the interview, the university students learned new words and constructed correct sentences in French. Also, the learners approved that this research had any negative effects.

Similarly, Yavuz (2017), Çetinkaya, Hamzadayı (2014), Coşkun (2013), Şahenk Erkan (2013), Kara (2011), Sülükçü (2011), and Saraç-Süzer (2008) have studied writing and reading activities in Foreign Language Teaching [19], [20], [21], [22], [23] and [24] and [25]. These works of research justify the claim that learners can improve their reading and writing skills after completing these types of activities. In addition, Lee and Muncia (2006) and Alan (2005) approved that the students could answer the questions easily and productively and that the learners had written French with minor false lexical syntactic and orthographic answers in French [26] and [27].

\subsection{Recommendations}

The recommendations to the other researchers are listed below:

(i). This study should extend to various countries around the world;

(ii). This study should be realized in primary and secondary educational stages; (iii). It should evaluate EFL, FFL, and other different foreign languages classes;

(iv). It should be utilized in A1, B1, B2, and C1 language levels; and

(v). It should be developed in various listening, reading, speaking, and writing activities.

\section{REFERENCES}

[1] Ambrose, D. \& Sternberg, R. J. (Editors) (2016). Creative intelligence in the $21^{\text {st }}$ century: Grappling with enormous problems and huge opportunities. In Ambrose, D. \& Sternberg, R. J. Previewing a collaborative exploration of creative intelligence in the $21^{\text {st }}$ century (3-20), USA: The Netherlands, Sense Publishers.

[2] Eng, N. (2015). Excellence redefined for the $21^{\text {st }}$ century. Symposium: $21^{\text {st }}$ century excellence in education, Part II, Soc, Number: 52, 237-241. doi: 10.1007/s12115-015-9893-3.

[3] The $21^{\text {st }}$ century teacher: Modern foreign languages (2010). Retrieved June 27, 2017 from http://www.vln.school.nz/file/download/54083.

[4] Eaton, S.E. (2010). Global trends in language learning in the twenty-first century. USA: Calgary: Onate Press.

[5] Common European Framework of References for Languages: Learning, Teaching, Assessment. Retrieved 25, June 2017 from

https://www.coe.int/t/dg4/linguistic/Source/Framework_EN.p df

[6] Di Paolo, A. \& Tansel, A. (2013). Returns to foreign language skills in a developing country: The case of Turkey. Retrieved June, 272017 from http://www.ub.edu/irea/working_papers/2013/201319.pdf, Europe: Spain: Barcelona, Universitat de Barcelona.

[7] Grabe, W. \& Stoller, F. (2002). Teaching and researching reading. USA: Harlow: Pearson Education.

[8] European Commission education and training. first European survey on language competences (Final Report). Retrieved June, 272017 from

http://ec.europa.eu/dgs/education_culture/repository/language s/policy/strategic-framework/documents/language-survey-fin al-report_en.pdf.

[9] Kaplan, R. B. (2002). The Oxford handbook of applied linguistics. USA: Oxford University Press.

[10] Dubin, F., \& Bycina, D. (1991). Academic reading and the ESL/EFL teacher. In M. CelceMurcia (Ed.), Teaching English as a second or foreign language ( $2^{\text {nd }}$ Edition) (195-215). USA: Boston, MA: Heinle \& Heinle.

[11] Grabe, W. (1991). Current development in second language learning research. TESOL Quarterly, 25(3), 375-406.

[12] Chastain, K. (1988). Developing second-language skills: Theory and practice. ( $3^{\text {rd }}$ Edition) USA: San Diego, CA: Harcourt Brace Jovanovich .

[13] Carlisle, J. F. (1995). Morphological awareness and early reading achievement. In L. B. Feldman (Ed.) Morphological aspects of language processing (189-209). USA: Hillsdale, NJ: Erlbaum. 
[14] McCarthey, S.J., \& Garcia, G. E. (2005). English language learners' writing practices and attitudes. Written Communication, 22 (1), 36-75 .

[15] Graham, S., \& Herbert, M. (2011). Writing to read: A meta-analysis of the impact of writing and writing instruction on reading. Harvard Educational Review, 81(4), 710-744 .

[16] Kinsella, K. (2009). Twelve tips to teach the reading-writing connection. Retrieved August 02, 2017 from http://penningtonpublishing.com/blog/reading/twelve-tips-toteach-the-reading-writingconnection .

[17] Creswell, W. (2003). Research design: Qualitative and quantitative, and mixed approaches. USA: CA: Thousand Oaks, SAGE Publications.

[18] Nauplie vous invite. Retrieved June 31, 2017 from http://www.bonjourdefrance.com/exercices/nauplie-vous-invi te-.html.

[19] Yavuz, A. (2017). Some suggested practices to develop speaking skills and communicative competence of B1 level EFL learners at tertiary level. Doctoral Dissertation, Turkey: Ankara: Hacettepe University.

[20] Cetinkaya, G. \& Hamzaday1, E. (2014). Sesbirimsel metin diktesi uygulamalarının A2 düzeyindeki öğrencilerin yazma becerileri üzerindeki etkisi (The effect of phonemic text dictation practices on A2 level students' writing skills). Electronic Journal of Social Sciences, Spring 2014, 13 (49), $1-15$.

[21] Coskun, O. (2013). La place de la competence écrite dans les nouvelles approches de l'enseignement de Francais Langue Étrangere: Le cadre Européen Commun de Référence pour les Langues et la réalisation de la perspective actionnelle (The place of written competency in new approaches to teaching French Foreign Language: The Common European
Framework of Reference for Languages and application of the action-oriented approach). Doctoral Dissertation, Turkey: Ankara: Gazi University.

[22] Sahenk Erkan, S. S. (2013). Investigation of reading texts in B1 level in French Language Teaching. Journal of Educational and Instructional Studies in the World, February, March, April 2013, 3 (1), 99-104.

[23] Kara, M. (2011). Avrupa Dilleri Öğretimi Ortak Çerçeve Metni doğrultusunda Türkçe öğrenen yabancılara A1-A2 seviyesinde Türkçe Öğretim Programı örneği (A sample of Turkish Language Teaching Syllabus for foreigners who learn Turkish at A1 \& A2 level in terms of Common European Framework). Zeitschrift für die Welt der Türken Journal of World of Turks, 3 (3), 157-195.

[24] Sülükçü, Y. (2011). Yabancılara Türkçe öğretiminde (Temel Seviye A1) Bilgisayar Destekli Materyal geliştirme ve bunun ögrenci bașarisina etkisi (Developing Computer Assisted Materials in teaching Turkish to foreigners (Basic User A1) and its effects on students' success). Doctoral Dissertation, Turkey: Konya: Selçuk University .

[25] Saraç-Süzer, S. (2008). Okuma ve yazma becerileri öğretimi: Süreç izlencesi ve küresel sorunlar (Teaching of reading and writing skills: Process syllabus and global issues). Journal of Human Sciences, 5 (2), 1-14.

[26] Lee, S. H., \& Muncie, J. (2006). From receptive to productive: Improving ESL learners use of vocabulary in a postreading composition task. TESOL Quarterly, 40(2), 295-320.

[27] Alan, S. (2005). Fransızca öğrenen Türklerin yaptıkları biçimbilimsel ve sözdizimsel yanlışların çözümlenmesi (Evaluation of the syntactical and morphological errors from Turkish students in French). Doctoral Dissertation, Turkey: Ankara, Ankara University Social Science Institute. 